\title{
RECONCILIATION IN THE SOUTH AFRICAN \\ POLITICAL CONTEXT: \\ A CHALLENGE TO THE CHURCH FOR COMMUNITY BUILDING ${ }^{1}$
}

\author{
KTh August \\ Department of Practical Theology \\ Stellenbosch University
}

\begin{abstract}
Reconciliation is a very central teaching and practice fundamental to the life and witness of the Church. The position taken in this paper is from the Judeo-Christian perspective, which is essentially a christo-centric perspective on reconciliation. Whereas the South African public has politically come through a process of Truth and Reconciliation in the post-apartheid democratic dispensation, the church in its public responsibility has to ask itself what the implication of this political process is for our society. Did the TRC process achieve its goals? Did the TRC succeed in being a part of the process of the healing of our nation? How is the church to understand political reconciliation? Is there a correlation between political reconciliation and the church's understanding thereof in our context that can be utilized to build community and ubuntu? The article seeks to find ways in which the church's nature of koinonia in partnership with government and civil society (in realising that "critical to the process is the fact that reconciliation and reconstruction or transformation are flip sides of the same coin") could help to handle transformation and reconciliation in such a way that national unity and the well being of all South Africa citizens can be pursued?
\end{abstract}

Key Concepts: Reconciliation, koinonia, community building

\section{Introduction}

Our country has just come through a process of dealing with the legacy of apartheid by means of the Truth and Reconciliation Committee (TRC). ${ }^{2}$ This process seems to me as a patriotic South African to be an appropriate framework for my paper. It is important to understand the context in which the TRC was called into being, which is also the context that forms the background to my paper.

The TRC was based on the final clause of the Interim Constitution, which reads as follows:

This Constitution provides a historic bridge between the past of a deeply divided society characterised by strife, conflict, untold suffering and injustice, and a future founded on the recognition

\footnotetext{
Paper delivered at the International Reformed Theological Institute July 2003 in Indonesia.

On 19 May 1995 President Mandela signed the Bill entitled "Promotion of National Unity and Reconciliation" into law. In terms of this Act the President appointed the Commission "in consultation with the cabinet" to deal with "gross human rights violations that took place between 1 March 1960 and 5 December 1993". This was the period when liberation movements were banned.
} 
of human rights, democracy and peaceful co-existence and development opportunities for all

South Africans, irrespective of colour, race, class, belief or sex.

The pursuit of national unity, the well being of all South African citizens and peace require reconciliation between the people of South Africa and the reconstruction of society.

The adoption of this Constitution lays the secure foundation for the people of SA to transcend the divisions and strife of the past, which generated gross violations of human rights, the transgression of humanitarian principles in violent conflicts and a legacy of hatred, fear, guilt and revenge.

These can now be addressed on the basis that there is a need for understanding but not for vengeance, a need for reparation but not for retaliation, a need for $u b u n t u^{3}$ but not for victimisation...

\section{The Truth and Reconciliation Process}

In the face of this process the question why was a TRC needed? can be answered as follows: Our country has a long history of political strife. These conflicts of the past led to a deeply divided society where there was much suffering and many gross violations of human rights.

Now that we have a democratic government, it is important to find out what happened in the past so people will at last know who committed these violations and what happened to their friends, relatives and communities. Once we know, we can begin to put the past behind us and move with hope into a peaceful future.

Whilst the objectives of the Commission were to promote national unity and reconcileation in a spirit of understanding, which transcends the conflicts and divisions of the past, the mandate was to provide a record of gross human rights violations committed between 1 March 1960 and the 6 December 1993, by both the upholders of apartheid and the liberation movements; to identify the victims and their fate; to recommend possible measures of reparation; to process applications for amnesty and indemnity; and to make recommendations with regard to measures necessary to prevent future gross human rights violations.

This ideal was reiterated by Archbishop Tutu as chairman of the TRC when he said on December 161995 " Absolutely central to our concern in the work of our Commission is helping our land and people to achieve genuine, real and not cheap and spurious reconciliation... We are meant to be a part of the process of the healing of our nation, of our people, all of us, since every South African has to some extent or other been traumatised. We are a wounded people because of the conflict of the past, no matter on which side we stood. We all stand in need of healing."4

And now seven and a half years down the line on 15 April 2003 when the report of the TRC was tabled, archbishop Tutu in commending the Report to the National Parliament expressed on behalf of the Commission his thanks "for an incredible privilege to preside over the process of healing a traumatized and wounded people." Referring to the thousands of South Africans who came to the Commission to tell their stories he said: "They have won our country the admiration of the world: wherever one goes, South Africa's peaceful transition to democracy, culminating in the truth and reconciliation process, is spoken of

The concept "Ubuntu” was popularised by Archbishop Tutu (cf. Hulley, L et al 1996 Archbishop Tutu). The term Ubuntu derives from the expression Umuntu ngumuntu ngabanye Bantu. Not an easily translatable Xhosa concept, generally this proverbial expression means that "each individual's humanity is ideally expressed in relationship with others and, in turn, individuality is truly expressed."

Tutu's address to the first gathering of the TRC. 
almost in reverent tones, as a phenomenon that is unique in the annals of history, one to be commended as a new way of living for humankind. Other countries have had truth commissions, and many more are following our example, but ours is regarded as the most ambitious, a kind of benchmark against which the rest are measured." In conclusion, he remarked that "the conflict areas of the world" makes "it increasingly clear that there is not much of a future for them without forgiveness, without reconciliation." And yet, to those in the world who are locked in deadly conflict, it erroneously appears as if South Africans have been blessed by God to become a blessing to them in order to show that peace that a just solution is possible - it is a case of the "wounded healers."

Our question would therefore be a reasonable one if we should ask: What did the TRC achieve and what will its legacy be?

\subsection{A Look at a Political Evaluation from the President ${ }^{6}$}

In this regard, President Mbeki remarked as follows at the tabling of the Report on 15 April 2003:

Our assessment of the TRC's success cannot $\ldots$ be based on whether it has brought contrition and forgiveness, or whether at the end of its work, it handed us a united and reconciled society. For this was not its mandate. What the TRC set out to do, and has undoubtedly achieved, is to offer us the signposts in the long march to those ideals.

Referring to the preamble to the Promotion of National Unity and Reconciliation Act, which captured the objectives of the TRC, Mbeki pointed out that the pursuit of national unity and the well being of all South African citizens and peace require reconciliation among the people of South Africa and the reconstruction of our society. The occasion of the receipt of the TRC Report should give us as nation an opportunity to reflect on these larger and fundamental objectives, which should inform us all as we work to give birth to the new South Africa. These larger questions of national unity, national reconciliation and national reconstruction, which stand at the heart of what our country will be, did not fall within the mandate of the TRC. The TRC was therefore but an important contributor to the achievement of the larger whole, occupying an important sector within the larger process of the building of a new South Africa.

As stated in the Act, the TRC had to help us to establish the truth in relation to past events as well as the motives for and circumstances in which gross violations of human rights occurred, and to make the findings known in order to prevent repetition of such acts in future.

It had to help us to promote understanding and avoid vengeance, to extend reparation to those who had been harmed and discourage retaliation, to rely on the spirit of ubuntu as a deterrent against victimisation.

The issues arising out of the TRC Report, Mbeki claims, form part of the panoply of programmes that define the first steps in a journey that has truly begun.

The situation we face demands that none of us should succumb to the false comfort that now we live in a normal society that has overcome the legacy of the past, and which permits us to consider our social tasks as mere business as usual.

Rather it demands that we act together as one people to address what are truly national tasks, viz. the challenges of securing the well being of all South African citizens by:

Cf. Henri Nouwen as quoted by Tutu in his forward to the Report of the TRC (15 April 2003).

Mbeki: Tabling of TRC Report (15/04/2003) http://www.polity.org.za/pol/search/content/? show=34775 
- creating a non-racial society,

- building a non-sexist society,

- eradicating poverty,

- addressing the needs of the most vulnerable in our society, the children, the youth, people with disabilities and the elderly.

\subsection{The Response by The Centre for the Study of Violence and Reconciliation (CSVR)}

The Centre expressed its appreciation for "the unprecedented space and attention provided by the TRC to victims and survivors of gross human rights violations." The Centre believed that the public nature of the TRC's work has afforded all South Africans an opportunity to begin the difficult process of coming to terms with the atrocities of the past. However CSVR Director Graeme Simpson pointed out that "it is important to remember that the TRC was just the beginning of a larger and long-term process of building national reconciliation. In order for reconciliation to be sustainable in our society, it has to be based on a prioritisation of the needs of victims of gross human rights violations. In this respect there is still a considerable amount of unfinished business that needs to be addressed in the wake of the TRC."

Referring to issues of reparation, prosecutions and legal actions against perpetrators of apartheid-era atrocities, blanket amnesty, further information gathering and truth-seeking and access to information he challenged the government, now that the TRC's work has been concluded, to take forward these substantive issues.

What he has to say about reconciliation is prominent to our theme, viz. that it must remain on the national agenda. Whilst the TRC provided a foundation, the process of reconciliation has only just started. Reconciliation between victims and perpetrators within communities divided by conflict, as well as between black and white South Africans, requires concerted efforts by government and civil society. There needs to be continued space in society to explore the meaning of reconciliation in relation to issues of race and identity within South Africa.

If reconciliation is to be sustainable in South Africa, then now is the time when government must demonstrate its commitment and its political will to implement - and even go beyond - the recommendations of the TRC. This must be done both out of a moral commitment to the 16,500 victims who have testified before the Commission, as well as to the majority of black South Africans who suffered under Apartheid.

\subsection{Other Responses}

- The Inkhata Freedom Party (IFP) who for years fought a bloody turf war in KwazuluNatal with supporters of the ruling African National Congress (ANC) during apartheid brought a legal challenge, which delayed the final report since 1998. The report described the IFP, under the leadership of Mangosuthu Buthelezi, as the "primary nonstate perpetrator... responsible for approximately $33 \%$ of all violations reported to the commission." Buthelezi took umbrage and a settlement was presented to court in which the TRC agreed to certain changes to its final report. It also agreed to include an appendix to the agreement in which the IFP and its leader could express their views

CSVR Press Statement, Final Repport not the Last Stop on the Road to Reconciliation, 21 March 2003 http://www. csvr.org.za/press.htm 
about the changes to the report. However, the IFP national chairman was quoted as saying that the final TRC report is a "flawed product of a flawed process conducted with flawed motives." 8

- The Khulumani Non-Government Organization (NGO) issued a statement saying that while it acknowledged the "complexity of the process that the government is faced with", the process of reparations was an integral "part of the healing of the nation."

- The Apartheid Debt and Reparations Campaign, Jubilee South Africa, said the issue of accountability for reparations for apartheid human rights violations was still unresolved and vowed to continue its fight for compensation for survivors. ${ }^{10}$

- The Institute for Democracy in South Africa, by mouth of its executive director, Paul Graham is of the opinion that the report of the TRC, "to a large extent, gains its significance and stature from the extent to which the politicians accept it, adopt it and convey its meaning to their supporters."

As to the Report's significance, Graham added: "It is the end of an important chapter in our transition. What remains now is for a commitment to be made to reparations and more importantly, implementation of some of the recommendations the TRC made in its initial reports, such as the development of a culture of democracy and non-racialism. These things are still visions to be achieved in South Africa." The TRC report was being given to a nation who, "while it is a new state, nevertheless has inherited the responsibilities of the past and therefore needs to take responsibility to declare publicly that a period is closed and a new period has begun," he added. ${ }^{11}$

The TRC recommendations range from institutional reforms and legal interventions to administrative transformation, memorials and monuments, community rehabilitation and monetary payments.

The questions that need to be asked are: Did the responses provide the foundation for sustained work to heal wounded souls? Could Government's attitude inform the effort of sectors of our society that need to be mobilised to nurse and heal the wounds of the past?

In concluding this section, the following opinion ${ }^{12}$ serves as a good summary on the responses to the TRC report:

President Mbeki has shown sane, wise and balanced statesmanship in his response on behalf of the South African Government to the TRC Report and its recommendations. It is only a matter of weeks since the final two volumes of the report were presented to him by Archbishop Tutu. ${ }^{13}$ The government has honoured its undertaking to make a response as soon as the full report was in its hands and it has done so with commendable speed.

In particular, provision has been made for reparation to 22000 victims of gross human rights violations who appeared before the Commission.

Each of them is to receive as a matter of urgency a one-off grant of R30 000. This is acknowledged to be a mere token in relation to the acute suffering they have endured, but it

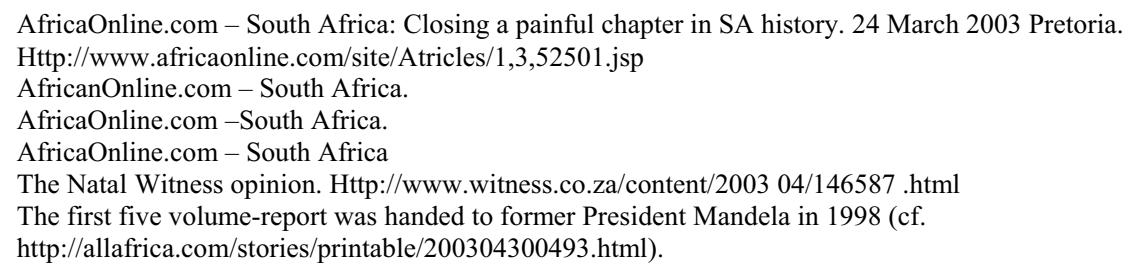


is nonetheless an appropriate tangible sign of support from the public purse, helping to balance out the amnesty, which many perpetrators of the violations have received.

No general amnesty is to be allowed for those who, for whatever reason, refused to participate in the TRC process. President Mbeki correctly points out that such amnesty would fly in the face of the principle of accountability and full disclosure which under girded the work of the TRC. Nor is action to be taken against firms and corporations that are held to have benefited from apartheid. In addition, the TRC's recommendation of a oneoff "wealth tax" to cover the cost of reparation is not to be imposed. Reparation will come instead from general revenue. Every white South African in particular should be willing to contribute for not one of them did not benefit in some measure from the apartheid system.

These and other decisions, such as the acceptance of the need to engage in long-term reconstruction and development in broken communities, are all to be welcomed. It is indeed refreshing to find the language of the RDP coming back into vogue in government circles.

By contrast, the Inkatha Freedom party's latest vitriolic attack on the TRC, and on its esteemed chairman in particular, is very unfortunate. It is true that in the battle for political turf in the eighties and nineties the members bore a good deal of the brunt, but they too were unquestionably involved in both initiating and executing a great deal of the violence. Their refusal to participate in the TRC process was a mistake that will perhaps haunt them for a long time.

The TRC was subject to the human limitations of any social experiment or endeavour, but its achievements far outweighed any limitations. The Government's response to its lengthy and painstaking report is a tribute to its admirable contribution to a costly reconciliation and healing in our body politic. ${ }^{14}$

\subsection{The TRC Report: The Response from State and Religious Leaders}

President Mbeki on meeting with the country's national religious groups on 30 April 2003 to chart a way forward for nation building and reconciliation, declared that government would form a partnership with different religious groups to work together in the country's healing and reconciliation process.

He said that some of the religious leaders made some very moving presentations on the issue of healing because of their concerns. There are serious challenges of ensuring we go through this healing process. It will certainly be one of the matters that will be taken up. ${ }^{15}$

"We cannot say really because the TRC presented its report that the matter is closed. The TRC dealt with the matter of victims in the context of the law. The healing question has to do with the involvement of millions of South Africans."

South African Council of Churches (SACC) president Mvume Dandala concurred with Mr Mbeki that religious leaders needed to foster a sense of reconciliation for all the people. "If we are going to be successful in taking up the process of reconciliation, we have to be more and more of a movement to expose people to what other people are doing. The matter of rebuilding the nation should not be looked at by government only but is a matter for all the people of South Africa." 16

Cf. The Natal Witness opinion. Http://www.witness.co.za/content/2003 04/14657 .html

15 CSVR Press Statement, Final Report not the Last Stop on the Road to Reconciliation, 21 March 2003

http://www.csvr.org.za/press.htm

16 CSVR Statement 21 March 2003. 
The Chairperson of the National Religious Forum, Ashwin Trikamjee, challenged leaders to encourage their members to volunteer their services to their communities, to expose them to different cultures and provide skills to other South Africans to foster nation building. ${ }^{17}$

\section{Towards Understanding the Political Motive Behind and Public Conception of Reconciliation in SA}

John de Gruchy ${ }^{18}$ when referring to the secret talks between Mandela and the government at the time of the writing of the Kairos document, remarked that those who were engaged in the liberation, and who came to know about these talks, were at first concerned that Mandela had sold out and had engaged in an exercise of cheap reconciliation. But that was not what Mandela was doing. As far as Mandela was concerned there could be no negotiated settlement unless the government was prepared to accept the goal of a non-racial democratic society. There could be no reconciliation without liberation and justice.

All the evidence indicates that although Mandela chose the reconciliation route and pursued it with conviction, he refused to demean either himself or his cause through compromises, which would have undermined the cause of justice.

Throughout the negotiated settlement, the Interim Constitution and the Government of National Unity, the pursuit of national unity, the well being of all South African citizens, and peace were the ultimate objectives.

The adoption of the constitution with its clause on national unity and reconciliation laid a secure foundation for the people of South Africa to transcend the division and strife of the past, which generated gross violations of human rights; the transgression of humanitarian principles in violent conflicts; and a legacy of hatred, fear, guilt, and revenge as born out by the TRC report.

But how does the general public in South Africa come to an understanding of reconciliation? How does the public embrace reconciliation? We are all agreed that in order to build national unity we need reconciliation and not retribution. Charles Villa-Vicencio writes "political reconciliation is, by definition, a modest exercise - the beginning of a journey away from a destructive past to the possibility of a different kind of tomorrow."19

Reconciliation in the public sphere has primarily to do with embracing the present as a basis for committing ourselves to a better future. ${ }^{20}$

National reconciliation is as varied in expectation and content, as the many journeys it involves. It would be wrong to either limit the number of different journeys or dogmatically prescribe how they are to be undertaken. Having said this, at the broadest level the following criteria need at least to be borne in mind in pursuit of the national goal. National reconciliation does not necessarily involve forgiveness. Politically, people live together quite well without necessarily having to work through all that forgiveness involves. It involves peaceful coexistence, as the first step towards greater, perhaps even more intimate unity later.

7 CSVR Statement, 21 March 2003.

18 John W de Gruchy, 1997 “The Dialectic of Reconciliation” in: The reconciliation of peoples. Baum, G and Wells, H 1997. Geneva: WCC publications.

19 Institute for Justice and Reconciliation vol. 1. Issue 11April 2003 p.1.

20 Mbeki in Mbeki: Tabling of the TRC Report (15/4/2003) p.9 calls it “the entering into a peoples' contract for a better tomorrow." 
It involves acknowledgement. It is impossible to deal with a problem, whether past or present, tangible or of a subjective kind, if it is not acknowledged and faced.

Critical to the process is the realisation that reconciliation and reconstruction are flip sides of the same coin. In the words of Mbeki as quoted by Villa-Vicencio: "It is a very delicate thing to handle the relationship between these two elements (transformation and reconciliation). ...If you handle the transformation in a way that doesn't change a good part of the status quo, those who are disadvantaged will rebel, and then goodbye reconciliation."

I agree with De Gruchy in Baum and Wells (1997:26) that it is impossible to make adequate reparation for all the injustice and hurt caused by apartheid and the centuries of colonialism that preceded it, but that it is essential that as much is done as possible to overcome the legacy of apartheid and redress historic wrongs. What the government has set out to achieve by the RDP is a clear effort to redress the wrongs of apartheid in a broad sense and to overcome the past. ${ }^{21}$

And now, on the eve of a decade of democracy, how far have the notion of reconciliation evolved in our country? What in the understanding of the public has happened around reconciliation?

The first Reconciliation Barometer survey conducted by The Institute for Justice and Reconciliation (IJR) has found that almost $30 \%$ of South Africans could not provide any meaning for reconciliation. ${ }^{22}$

Amongst South Africans able to provide some meaning of reconciliation, notions of forgiveness are the most widely held, with $23 \%$ of all responses citing this meaning.

The rationale behind this statistic is open to debate. Did Archbishop Tutu's call for reconciliation through forgiveness during the TRC find resonance in South African minds? Or do South Africans view reconciliation within a religious paradigm, inculcating theological demands for confession, repentance and, most importantly, forgiveness?

Hereafter, responses entailing notions of unity $(16 \%)$, peace $(13 \%)$ and racial integration $(10 \%)$ recur most commonly. In the light of the country's violent past, and the ongoing political violence in KwaZulu-Natal, it is no surprise that for many reconciliation is nothing more than an end to violence and bloodshed.

The survey further reveals the following responses: forgetting about the past $(9 \%)$, ideas of cooperation (5\%), dealing with the past (5\%) and then dealing with difference $(5 \%)$.

Bar associations with forgiveness and forgetting, other forms of active confrontation of the past, such as apologies, acknowledgement, redress or confession, do not feature very prominently.

Somewhat unexpectedly, reconciliation is only associated with issues of material compensation, financial redress and socio-economic development in less than $4 \%$ of answers.

Equally surprising is the lack of wide-ranging mention of first generation human rights $(2 \%)$, so important for creating a legal and political framework for reconciliation.

On the question: Why is this so? The IJR gives the following interpretation:

The majority of South Africans view socio-economic development, racial reconciliation and democratic consolidation as separate and independent processes.

21 Central to the RDP is the redistribution of land; fundamental change in education, health, and housing policies; and far-reaching affirmative action programmes in the public as well as private spheres (cf. De Gruchy, in Baum and Wells, 1997: 26).

22 Cf. The SA Reconciliation Barometer, vol1. Issue 1 April 2003 (Cape Town: Institute for Justice and Reconciliation) p2. 
The IJR warns, "There is an inherent danger in not recognising the mutually symbiotic relationship between these processes." The people do not recognize the significance of development, economic redress and tangible transformation for reconciliation.

As it is apparent that there is a dichotomy regarding reconciliation and economic redress in the SA context, and whilst the TRC was greatly inspired by religious insight, I intend to show that an understanding based on the Judeo-Christian perspective of reconciliation has a more holistic inclusive view of a multi-sectoral setting. This will prepare the framework for the following sections that wants to portray the church as catalyst for reconciliation in the SA context.

\section{A Judeo-Christian Perspective on Reconciliation}

The most dangerous legacy of the Christian understanding of reconciliation is the desire to reduce reconciliation to a matter of "forgive and forget." ${ }^{23}$ But the basic idea in reconciliation (Gr. katallassein) is that "of making peace after a quarrel, or bridging over an enmity." ${ }^{24}$ Now the way to do that is to deal with "the root cause of the hostility.",25

In all the passages ${ }^{26}$ where Paul deals with reconciliation it is clear that the root cause is the $\sin ^{27}$ of humanity, which inevitably arouses the opposition of the holy God. If there is to be harmony then that sin must not be glossed over, but really dealt with. In one aspect the work of Christ was doing away with the enmity ${ }^{28}$ and $\mathrm{He}$ did this by dealing with sin. $\mathrm{He}$ judged it. He met the demands of a righteous God concerning it. He defeated it and took it out of the way. ${ }^{29}$ Notice that this is a distinctively Christian idea. The other religions of the world, in either ancient or modern times, display a somewhat different understanding of the purity and holiness of God and of the ill desert of $\sin ^{30}$ It is a thought unpalatable to humankind that God's holiness must be taken seriously in any attempt to solve the problem of reconciliation. The Christian thought of forgiveness as something so wonderful (almost to be unbelievable) is due to the Christian perspective on the necessity for the tremendous moral energy of the cross for it to be effected. ${ }^{31} \mathrm{As}$ Wells ${ }^{32}$ states it: "It is precisely the long Christian tradition of the all-sufficient sacrifice of Christ that has made animals sacrifices unnecessary and meaningless for us."

Having stated this, it is also necessary to shortly look at atonement and the cost of reconciliation. It would be easy to discard or trivialize the doctrine of atonement as religiously and culturally antiquated. The truth in all the religious cultic means of atonement

David J Livingston, Healing Violent Men, and Minneapolis: Fortress 2002.

Leon Morris, The Cross in the New Testament, Devon: Paternoster Press (pp. 247-252).

Leon Morris, The Cross in the New Testament, (pp. 247-252).

Cf. Rom. 5:10f; 2 Cor. 5; Eph. 2:11-16; Col. 1:19-22.

27 Sin is the violation of the relationship between God and man; and between man and man. Sin is the cause of the ruptured relationship.

28 This has effects both Godward and manward, for a real and deep change of the relationship between the two means a change on both sides (cf. Forsyth, 1948, The Work of Christ, p75).

29 Emil Brunner in Morris (1997: 250) says in dealing with reconciliation, "It is not primarily the sense of guilt which has to be removed, but the actual stain of guilt itself. Many men have scarcely any sense of guilt at all; it is not aroused in them until they come into contact with Christ. And it is in Christ alone that we all come to know what our guilt really is. The first element, therefore, in the act of reconciliation is not the removal of this subjective sense of guilt, but the knowledge that our guilt has been purged."

30 Cf. Morris, Leon 1979 The Cross in the New Testament, 251.

31 The Christian Gospel of the forgiveness of the wrong (reparation) is essentially needed for reconciliation. That is why St. Paul believes that "God was in Christ reconciling the world unto himself."

32 Wells, H 1997 "Theology of Reconciliation" in: The Reconciliation of Peoples, Baum G and Wells G, Geneva: WCC publications (p10-11). 
throughout history (the bloody sacrifices) is the recognition that our evil deeds cannot be taken lightly. Reconciliation is costly. God does not wink at our cruelty and injustice. Neither our petty failures and selfishness nor the gross social injustices in which we are implicated can be eliminated with an indulgent smile. The cross shows us that reconciliation is costly to God. It is not that God demands that someone else pay. On the contrary, it is God who, in Christ, offers reconciliation and bears the cost of our refusal. This oneness of Jesus Christ with God is the only way that Christ could become not only the Brother of the victims but also the one who atones for the guilty too. ${ }^{33}$

The resurrection too is an essential moment in the work of the atoning God. God also judged and pronounced sentence in the resurrection, which was the vindication of the victim, the triumph of all the persecuted of history and the judgement of the victimizers (Wells 1997).

The doctrine of atonement then can be a profound source of reconciliation among the perpetrators of crime and their victims. Yet, before the Cross, injustice and oppression are taken with absolute seriousness: this is the truth and justice aspect of reconciliation. For God is in total solidarity with the suffering victim. God is then the vulnerable One, the selfgiving One, who moves us not to revenge but to forgiveness.

A look at a Thomistic interpretation of reconciliation gives us a framework from within his sacramental theology. Aquinas identified four distinct, though interconnected, moments in the sacrament of reconciliation: contrition, confession, satisfaction, and absolution. These four moments embody a kind of phenomenology of the healing (restoration) desired in reconciliation, each moment revealing a specific requisite dimension of healing. Applying Thomas's framework, we are able to establish a connection to the historical articulations of the deep symbol of reconciliation while at the same time answering the contemporary demands of social scientific conclusions about violence. Through his four aspects of reconciliation the practice has the capacity to regain its genuine character as a classic symbol of Christianity.

Contemporary reconciliation should maintain the fourfold structure mentioned above. This form addresses the issues of duration, accountability, responsibility, and community. The insights gleaned from Aquinas are foundational points for reconstructing an appropriate and responsible theology of reconciliation. These insights offer us a glimpse at how this deep symbol of the Christian tradition enchants us. The hope and responsibility that come with reconciliation profoundly alter the response one has to the perpetrator within the church community. If a person is a friend or a member of the worshipping community it is difficult to simply dismiss or to demonize such a person. Reconciliation offers an alternative to demonising a person. This deep symbol calls us to join the person in the difficult journey of developing a contrite heart, confessing in an accountable manner, and responsibly compensating, as far as possible, for the destruction caused by the violation. In the reconciliation process, then, because the victim has been brought by God's reconciling grace to forgive the tormentor, the tormentor, having been prompted to repent of the evildoing, can engage in rebuilding his or her humanity. ${ }^{34}$ As the Christian community stands with the perpetrator in this process, it incarnates the symbol of reconciliation and

33 Moltman speaks in this regard of God who suffers vicariously "for us" and "for many" as our representative. By bearing human guilt God transforms it into his (God's) own suffering. (cf. Jürgen Moltmann, Jesus Christ for Today's World. Minneapolis: Fortress Press, 1994 p.40).

34 Robert J Schreiter, Reconciliation: Mission and Ministry in a Changing Social Order (Maryknoll, NY: Orbis Books, 1992), p.45. 
offers a glimpse of the abundant grace the church claims as its central message. And above all, the healing in authentic reconciliation leads to the restoration of life in community.

Even in the Church this does not always happen, and it is rarely a swift or simple process (Wells). Sometimes "peaceful" coexistence is all that can be achieved. People cannot be merely exhorted or manipulated into truly heart-felt reconciliation by a wellmanaged therapy or process. The wounded healer role of the victim and the sanctifying role of the reconciling community are most crucial elements in this process of restoration.

In the light of the aforementioned, the idea of a TRC is, in all probability, borrowed from the Roman Catholic model of penance, confession and absolution. The very language of "truth" and "reconciliation" has been central to the Christian tradition since its inception. The spectrum of themes such as memory, confession, truth and forgiveness is so central to Christian tradition and the Bible and so relevant to recent historical events that Christians need to be made aware that the TRC was a political means. Even more so, since South Africa is, nominally speaking, an overwhelmingly Christian country, the reconciliation project strikes some live chords in the hearts of the millions of nominal Christians. ${ }^{35}$ But, as Dirkie Smit has said," (The new) South Africa is not the kingdom of God.... The logic of Christian confession of guilt and forgiveness is not the logic of the public, political and economic world. The grammar of Christian contrition, confession and absolution is not the grammar of public jurisprudence., ${ }^{36}$

The question is whether the TRC with its notions of truth and reconciliation has moved the peoples of South Africa to fundamental transformation?

\section{The Challenge of the SA Sosio-Political Context after a Decade of Democracy}

Despite a decade of considerable political gains, there is much that still needs to be done. The transformation, reconstruction and reconciliation processes have only begun. The question that beckons answering is, who should take the responsibility to drive these?

The first Reconciliation Barometer ${ }^{37}$ survey reveals that $16 \%$ of respondents see Government as the sole bearer of primary responsibility.

Interestingly, a need for business to nurture a culture of corporate responsibility does not appear to have manifested itself in the minds of the majority of South Africans.

Further, the data reveals that $36 \%$ believe reconciliation should be the collective primary responsibility of business, government and individuals, with numerous other combinations of these role players being selected by a further $34 \%$.

The substantial abstract support for a multi-stakeholder reconciliation process is not, however, reflected in consequent results. The data reveals that only $19 \%$ of South Africans were willing to take considerable individual responsibility for reconciliation.

It is probable that some of the lack of responsibility is linked to notions of the reconciliation process being too large and distant a process for ordinary people to influence. Just short of $17 \%$ of South Africans believe they have considerable influence on the process of reconciliation.

Maluleke, TS, "National Unity and Reconciliation in South Africa” in: Mongezi Guma and Leslie Milton (eds.) 1997 An African Challenge to the Church in the 21 st Century, Johannesburg: South African Council of Churches.

36 Dirkie J Smit, "The Truth and Reconciliation Commission. Tentative Religious and Theological

Perspectives." in: Journal of Theology for South Africa. March. No.90. 1995 p.12.

37 The SA Reconciliation Barometer, vol. 1: 2003. 
In all likelihood, a greater portion of the $42 \%$ of South Africans claiming not to take very much or hardly any responsibility for reconciliation do so by choice.

A great deal of the euphoria and social momentum that drove the negotiated settlement has receded. People have gone back to their average, normal and routine thinking and behaviour.

The outcome of this situation is political stagnation, within which complacency of the powerful and increasing frustration for the weak becomes the norm. The outcome can be a new cycle of protest and repression between former allies. And what is more, it could lead to further alienation and estrangement, which could be counter productive for nation-building.

The potential for such conflict in South Africa is boldly present - seen in relation to issues such as reparations, poverty, unemployment, racism, sexism, HIV/AIDS and related concerns. Confronting these is up to the state and the nation as a whole.

Thorough going transformation and reconciliation require the social energy flowing from a greater willingness to take responsibility, and this should not be restricted to the political sphere. Business, civil society, labour and religious leaders also have a responsebility.

From the outset it was clear that the TRC could not deliver "national reconciliation" on its own. What is needed now is for Christian theologians, advocacy ministries, and churches to "deepen" and "reinforce" the TRC's considerable potential as a catalyst for national reconciliation and healing.

The question is how the church can assist in building community in South Africa after the TRC - the church with its life-enriching symbol of koinonia.

We have a new government that is bound by a new constitution to observe human rights principles. White and black people can meet and freely associate with one another. For many of them this is a liberating experience. On numerous occasions and within different spheres South Africans have manifested a growing awareness of belonging together.

Notwithstanding these encouraging signs of the emergence of a new South Africa, many events have made us aware that the old South Africa of discrimination and oppression has not simply disappeared. The vast majority of South Africans continue to live in dire poverty. Their living conditions have not yet changed. A serious discrepancy looms between the endeavours of the TRC to contribute towards healing in our land and the continuing and intensifying poverty that threatens the lives of so many people and hurts their dignity.

Can the churches and their members make a contribution towards a change that would help our country and our society to live up to its name: the new South Africa?

I suggest that a hermeneutical excursion of the Pauline usage of Koinonia might help the church to take its fundamental ministry of reconciliation seriously in our contemporary South African context.

\section{A Perspective on the Meaning of the Pauline Teaching of Koinonia for the Church's Role in Reconciliation}

Koinonia should serve as an imperative to Christians imploring them to be true to their faith and to bear witness by sharing the life-in-fellowship in our country in this day and age of our democracy. ${ }^{38}$

38 For the exposition on koinonia cf. Wolfram Kistner, "Koinonia: The Church creating Community" in: Mongezi Guma and A Leslie Milton (eds.) 1997 An African Challenge to the Church in the Twenty First 
The Greek word koinonia describes a close fellowship and sharing of life, frequently including the sharing of resources. The corresponding verb either means "to participate" or "to enable other to participate."

In profane language the adjective koinos pertains to something that is held in common in contrast to what belongs to the individual. Greek thinkers often used words from the koinonia word-family in their discussions on whether and how far communal property should be the basis of the political and social and economic order and in how far scope should be given to private property. ${ }^{39}$

The concept koinonia is especially found in the letters of the apostle Paul from whom the early church has also inherited the special meaning he gave to the word koinonia in the context of the Christian faith.

- Koinonia and Holy Communion

Participation in the life of the crucified and risen Lord changes their relationship towards one another. Allowing the community of believers to participate in the life of God and in the victory of the risen Lord that overcomes the forces of death, appears to be the main thrust of koinonia. Not to exclude or marginalize the poor and to share with fellow believers are of importance in the koinonia of the congregations.

- Koinonia and the sharing of resources

The fact that God has gone out of his way to overcome our forsakenness by entering our situation in Jesus as a human should motivate the Christians in Corinth to go out of their way to participate in the situation of the Christians in Jerusalem by sending them a collection as a symbol of their unity. Such koinonia would enrich the lives of those who contribute. "Those who were far off have come near" - involving the marginalized in acting as an instrument of spiritual growth that transforms human relationships.

- Koinonia and justification by faith

The purpose of justification is the transformation of humans into subjects who do justice and who liberate the truth that is being held captive by structures of injustice. God's final aim is not merely to save humans from his wrath, but to enable them by faith to fulfil his will, as revealed in the Torah, by living up to his revealed truth. ${ }^{40}$

- Koinonia as solidarity in sharing suffering

In Paul's proclamation of the Gospel, koinonia, the participation of Christians in the life of the crucified and the risen Lord through the Spirit, is the counter force against all forces of exclusion and division that disrupt humankind and creation. Christians should therefore give one another mutual support in suffering and should also share joy and suffering.

- Koinonia and the Triune God

The Nicene Creed of the 4th century offers the following fundamental insights of the Christian faith:

Century, Johannesburg (133-145). Groenewald (1932) regards koinonia in Paul as an inseparable relation to Christ, which includes all the other fellowship-relations by which the life of the believer is determined in relation to Christ and her fellow believers. This also includes faith and service, which covers the whole life of the believer (Groenewald, EP 1932 Koinonia (Gemeenskap) by Paulus. Amsterdam: Vrije Universiteit van Amsterdam).

39 W Kistner, 1997: 133-145.

40 Elsa Tamez in W Kistner, Koinonia. 1997 
- The God in whom Christians believe is not simply part of Creation and of human history, but is in control and ensures that it will eventually reach the aim for which it has been created.

- At the same time God is involved and present in Creation and in history and shares in particular the suffering of the discarded sections of human kind and of creation.

- The concept of koinonia has a special function in this confession of the Christian faith. The unity of the three persons of the Godhead is based on the closest fellowship and communication between the Father and the Son and the Holy Spirit with the result that each of the three shares the life and the involvement of the other. The Holy Spirit carries this treasure of unity and love into Creation and entrusts it to the Church as the koinonia, which is to transform human relationships and the relationship between humans and Creation.

- Koinonia and the cosmic dimension of the church

- From the outset the intervention of God in Jesus Christ confronted structures and practices, which excluded people from access to God's kingdom. God's love and forgiveness was to be extended to all humankind.

- In his new political, economic and cultural context within the Roman Empire the apostle Paul highlighted the cosmic dimension of the Church and of the koinonia that holds it together. The Church of Jesus Christ transcends all structures of exclusion. The Empire relied on controlling the resistance of subjugated nations by military power, by making use of the divisions between peoples and by co-opting collaborators. These were methods of control that were incompatible with the Gospel. The result was recurring persecutions of Christians in different parts of the empire.

This understanding of koinonia is basic for all Christians, united in their faith in their atoning, reconciling and redemptive Lord, Jesus Christ; and in their conviction that his followers are to be agents of reconciliation and promoters of love, justice, and peace (cf. Baum \& Wells, 1997: 184). Christians in the church are called by the gospel to be agents of reconciliation amongst groups and peoples caught in a history of conflict and enmity.

Unfortunately, the church also has to confess its inability and slothfulness to act as reconciler in conflicts between groups and peoples. There are sociological and theological reasons ${ }^{41}$ for the apparent difficulty that the church experiences to play a mediating role. But listening anew to God's Word according to Paul against the backdrop of the TRC's gallant attempt should urge many Christian-communities in South Africa to become reconcilers in our context and foster a church-transcending national (universal) solidarity, beginning with the poor and dehumanised oppressed.

The Biblical concept of koinonia, therefore can assist, guide and empower South African Christians to enhance the process of reconciliation in its fullest sense by publicly embodying their true being as people reconciled to God by the death of Jesus Christ (Rom 5:10)!

41 Ralph Premdas in Baum and Wells (1997: 186) has pointed out that "the successful incarnation of the church in a given community makes it difficult for the church to stand at a critical distance from it and take a nonpartisan view of the conflict in which it is involved." Examples of this phenomenon we find in Nazi-Germany during WWI and in South Africa during the apartheid-era. Theologically, there is the enormous ambiguity of scripture in dealing with the attitude of God's people to outsiders, whether individuals or collectivities. Passages proclaiming universal solidarity are few in comparison with the many passages that restrict solidarity to the believing community (Baum and Wells, 1997: 186). 


\section{Conclusion}

On the basis of koinonia, and the challenges of the TRC the church in South Africa has to build community by proclaiming and living out the Gospel, which implies our willingness to become involved in:

- Efforts to re-read the Bible from the perspective of marginalized people in order to help the people and the church to come to a deeper and clearer understanding of the meaning and implications of reconciliation for personal and civic life;

- partnerships with government, other institutions and poor communities in structural developmental campaigns to alleviate, with a view of eradicating poverty;

- addressing the needs of the most vulnerable in our society, the children, the youth, people with disabilities and the elderly;

- resisting structures of exclusion in church, in society, in the economy and in the state on a local, national and international level;

- educating the people to recognize the significance of development, economic redress and tangible transformation for reconciliation;

- endeavours to overcome denominational, religious, class, gender social and other divisions that obstruct the working of the Holy spirit inside, through and outside the church;

- initiating alternative economic and ecological models of responsible stewardship and sharing of resources;

- attending to the needs and the suffering of other than human sections of Creation;

- developing a responsible personal lifestyle that avoids the squandering of resources;

- developing an understanding that justice is not enough; it needs to be tempered by forbearance (the public function of tolerance and forgiveness in the NT);

- critically reviewing our Christian engagement in social actions of reconciliation with respect to our tradition, our teaching, our language, customs, and social patterns;

- restoring the identity and integrity of a people or community, which have been distorted by the racial superiority and the collective self- interest of other groups;

- raising leadership to take the movement forward - people of strong conviction who can promote the cause even in the midst of indifference and hostility.

It is my conviction that the TRC (although a political platform, but under the leadership and influence of two prominent Christians) has truly set out to offer us the signposts in the long march to those ideals of contrition and forgiveness in order to bring about a united and reconciled society. It has set in motion a process that should result in the healing of our nation. The TRC had to help us to establish the truth regarding gross violations of human rights in order to prevent repetition of such acts in future. The TRC has indeed helped us to understand and avoid vengeance, to extend reparation to those who had been harmed and to discourage retaliation. However it has to be re-emphasized that it could only serve to spur us on in actively engaging reconciliation.

The church is therefore greatly challenged by the TRC to critically engage this process of national reconciliation and to add value from its perspective of koinonia in reinforcing the fledgling democratic society and the long process of restoration and healing of the people of our country in order to ensure a dignified future for all. 


\section{BIBLIOGRAPHY}

Baum, G and Wells, W 1997. The Reconciliation of Peoples. Geneva: WCC Publications.

Brunner, Emil in Morris, Leone 1979. The Cross in the New Testament, Devon: Paternoster Press.

De Gruchy, John W and Wells, H 1997. Geneva: WCC Publications.

Forsyth, PT 1965. The Work of Christ. London: Collins.

Groenewald, EP 1932. Koinonia (Gemeenskap) by Paulus. Amsterdam: Vrije Universiteit van Amsterdam.

Guma, Mongezi and Milton, A Leslie (eds.) 1997. An African Challenge to the Church in the Twenty-First Century. SACC: Johannesburg.

Hulley, L. et al 1996 Archbishop Tutu. Cape Town: Human \& Rousseau.

Kistner,Wolfram 1997. "Koinonia: The Church creating Community” in: Guma, Mongezi and Milton, A Leslie (eds.). An African Challenge to the Church in the Twenty-First Century. SACC: Johannesburg.

Livingston, David J 2002. Healing Violent Men. Minneapolis: Fortress.

Maluleke, Tinyiko Sam 1997. "National Unity and Reconciliation in South Africa" in: Guma, Mongezi, and Milton, A Leslie (eds.). An African Challenge to the Church in the Twenty First Century. SACC: Johannesburg.

Moltman, J 1994. Jesus Christ for Today's World. Minneapolis: Fortress Press.

Morris, Leone 1979. The Cross in the New Testament. Devon: Paternoster Press.

Schreiter, Robert J 1992. Reconciliation: Mission and Ministry in a Changing Social Order. Maryknoll, NY: Orbis Books.

Smit, Dirkie J 1995. "The Truth and Reconciliation Commission. Tentative Religious and Theological Perspectives." in: Journal of Theology for South Africa. March. No. 90.

Tamez, E in W Kistner, 1997. "Koinonia: The Church Creating Community" in: Guma, Mongezi and Milton, A Leslie (eds.). An African Challenge to the Church in the 21st Century. Johannesburg: South African Council of Churches.

The SA Reconciliation Barometer, vol 1. April 2003. (Cape Town: Institute for Justice and Reconciliation).

Wells, H 1997. "Theology of Reconciliation” in: The Reconciliation of Peoples, Baum, G and Wells, H Geneva: WCC publications.

Institute for Justice and Reconciliation vol. 1. Issue 11 April 2003 http://allafrica.com/stories/printable/200304300493.html

Tutu in his forward to the Report of the TRC (15 April 2003).

http://www.polity.org.za/pol/search/content/?show $=34775$

Mbeki: Tabling of TRC Report (15/04/2003) http://www.polity.org.za/pol/search/content/?show=34775

CSVR Press Statement, Final Report not the Last Stop on the Road to Reconciliation, 21 March 2003 http://www. csvr.org.za/press.htm

AfricaOnline.com - South Africa: Closing a painful chapter in SA history. 24 March 2003 Pretoria. Http://www.africaonline.com/site/Atricles/1,3,52501.jsp

The Natal Witness opinion. Http://www.witness.co.za/content/2003 04/14657 .html 